\title{
Determination of Heavy Metals in Salt Water Periwinkle and Fresh Water Periwinkle in Port-Harcourt, Rivers-State
}

\author{
Don-Lawson Chioma, Nweneka Daniel Okechukwu, Oka Reminus
}

Department of Science Laboratory Technology, School of Science and Technology Captain Elechi Amadi Polytechnic, Rumuola, Rivers State, Captain Elechi Amadi Polytechnic, Rumuomei 100001, Port Harcourt, Nigeria

DOI: $10.36348 /$ sijcms.2021.v04i01.001

| Received: 26.12.2020 | Accepted: 11.01.2021 | Published: 14.01.2021

*Corresponding author: Oka Reminus

\section{Abstract}

This study of the composition of heavy metal, lead, iron, zinc and mercury in periwinkle tissues (Tympanotonosfiiscatus) were determined from different sampling stations in Mgbuoshimini Port Harcourt, Rivers State, Nigeria, using Atomic Absorption Spectrophotometer (AAS). The results obtained from the analysis of salt water and fresh water periwinkle tissues indicated lead $18.62 \%$, iron $70.08 \%$, mercury $11.20 \%$ and zinc $53.34 \%$ and that of fresh water periwinkle includes $17.48 \%, 71.79 \%$, mercury $10.71 \%$ and zinc $48.28 \%$ by percentage conversion. This comparative analysis implies that the fresh water periwinkle tissues have higher concentrations of iron and zinc which can be attributed to the dissolved mineral resources available in both salt and fresh water bodies. However, the concentrations of lead and mercury in these water bodies are above threshold limit which is quite a potential hazard for sea foods. In conclusion, comparison between the two water bodies showed that tissue samples from fresh water had higher concentration of metals in relation to salt water indicating potentials for accumulation, mainly due to differences in anthropogenic activities. $\mathrm{Hg}, \mathrm{Zn}, \mathrm{Fe}$ and $\mathrm{Pb}$ concentrations in tissue had values higher than the recommended limits in seafood by FAO/WHO however, regular monitoring is required to observe perturbations. In addition, sea foods obtained from the salt and fresh water bodies are potential sources of heavy metal poisoning, due to industrialization and non-regulatory use of the water bodies, thus, calls for adequate legislation and proper orientation on the use and protection of water bodies from heavy metalpoisoning.

Keyword: Periwinkle, Lead, Freshwater, Atomic Absorption Spectrophotometer.

Copyright $\odot 2021$ The Author(s): This is an open-access article distributed under the terms of the Creative Commons Attribution 4.0 International License (CC BY-NC 4.0) which permits unrestricted use, distribution, and reproduction in any medium for non-commercial use provided the original author and source are credited.

\section{INTRODUCTION}

Human activities has resulted to the pollution of the aquatic environment with heavy metals which has become a worldwide problem in recent years as reported by $[3,15]$ because they are indestructible and most of them have toxic effects on organisms (biotic andAbiotic factors). Many aquatic organisms for example Periwinkles have the ability to accumulate and biomagnify contaminants like heavy metals and polycyclic aromatic hydrocarbon in the environment. Among environmental pollutants, metals are of particular concern, due to their potential toxic effect and ability to bioaccumulate in aquatic ecosystems [6]. Studies on heavy metals in rivers, lakes, fish and sediments have been a major environmental focus especially during the last decade and heavy metals contamination of coastal water and sediment have been identified as a serious pollution resulting from industrialization according to [3, 21] Heavy metals contamination of river water is one of the major quality issues in fast growing cities because maintenance of water quality and sanitation infra-structure do not increase along with population and urbanization grow the specially in developing countries. Heavy metals and other fluvialcontaminantsinsuspensionor solution, do simply flow down the stream, form complexes with other compounds and settle to the bottom and are ingested by plants and animals or adsorbed to the sediment as reported by [14]. Consequently, aquatic organisms may acquire heavy metals into their body as reported by [9]. In this study, pollutants such as $\mathrm{Hg}, \mathrm{Pb}$, $\mathrm{Fe}$ and $\mathrm{Zn}$ were considered which are capable of bioaccumulation in the tissues of aquatic organisms. Monitoring of levels of contaminants in environmental receptors can include the measurement of bioaccumulation and toxicants in the bodie so for ganisms according to [20]. Some invertebrates especially molluscs and crustaceans can accumulate heavy metals in hundredfoldsandthereforecanraisethelevelwhichmaybeo fnosignificanceinwatertothepoint at which their tissue 
become highly hazardous to organisms that consume them. Heavy metals are accumulated by marine organisms to very high concentrations in their tissue and hence their body concentrations are easily measured. This may be influenced by rate of contamination and usually provides a time integrated measure of heavy metal supply over weeks, months or even years according to the specifics analysed [21, 18] then stated that the body content of a trace metal in any organism results from the net balance between the processes of metal uptake and metal loss. The Periwinkle (Tympanotonus fuscatus var radula (L.)) is a mollusc (Gastropods) of high commercial and economic value in the Niger Delta region of Nigeria. It is commonly distributed and found in the mangrove swamps and in tertidal zones of estuarine and marine waters of the Niger Delta. They are deposit feeders and bioindicators of heavy metal and hydrocarbon pollution in the aquatic environment. Deposit feeding has to do with sediment and benthic dwellers as stated by [9]. This implies the organisms have the ability to bioaccumulate heavy metals in their tissues in the process of deposit-feeding and so integrate the environmental conditions of the water and sediment over time. Studies have also been conducted to show the concentration of heavy metals in this molluscs and other commercial fish species of economic value to determine hazardous level of contaminants in them with regards to human consumption as reported by [5, 13]. Heavy metal concentrations in aquatic ecosystems are usually monitored by measuring their concentrations in water, sediments and biota which generally exist in low levels in water and attain considerable concentration in sediments and biota. The toxicity of heavy metals can result to reduce mental and central nervous system function, lower energy levels, and damage to blood compositions as stated by [1]. The lungs, kidneys, liver, and other vital organs are equally affected. Long-term exposure may result in slowly and progressive physical, muscular, and neurological degenerative processes that mimic Alzheimer's disease, Parkinson's disease, muscular dystrophy, multiple sclerosis, or endocrine disruption that can lead to infertility, or other abnormal metabolic situations. Heavy metals are dangerous because they are not easily excreted and therefore tend to bioaccumulate over time according to [11]. Lead in the environment arises from both natural and anthropogenic sources. Exposure can occur through drinking water, food, air, soil and dust from old paint containing lead. In the general non-smoking, adult population the major exposure pathway is from food and water. Lead is among the most recycled non-ferrous metals and its secondary production has therefore grown steadily in spite of declining lead prices as reported by $[19,9,16]$ stated that due to the dependence of the populace of Eagle Island in Port Harcourt on this water body for domestic water supply and its aquatic organisms (periwinkle) and other sea foods, as source of food nutrients, and considering the high level of industrial activity in the environment occasioned by the presence of oil industry and other activities of car battery chargers, it became imperative to assess this heavy metal in this water body to assess the level of heavy metals in this aquatic ecosystem in view of the health implications that cut across the food strata according to [5]. In Nigeria, the Federal Environmental Protection Agency (FEPA) is the body saddled with the responsibility for the protection of the environment. This agency has put in place laws and regulations guiding wastes management and disposal, emphasizing the treatment of wastes before disposal by the concerned industries. Adsorption processes have been known over the years as the primary method of metal ions removal from polluted environment as reportedby [4]. Heavy metals from wastes water effluents involved the use of chemical precipitation, evaporation, electrochemical treatment and the use of ion exchange resins [10]. In recent years, the use of biomaterials in the asorption process as adsorbent for the removal of heavy metal ions from polluted waste water has been an emerging field of interest for many researchers [8]. These biomaterials have gained importance due to their efficiency, low cost and ready availability. The unique ability of these materials of plant origin to bind metals has been attributed to be due to the presence of some functional groups on the surface of the adsorbent, which can attract or sequester these metal ions [7], demonstrates that the carboxyl groups found on the cell wall of dead algal biomass are potentially responsible for copper binding. Effluents from industries all over the world contained some of these hazardous heavy metal ions. Most industries in Nigeria discharge their effluents into the environment as report by [18], particularly nearby rivers untreated. The major reason of indulging in such unlawful act is to reduce cost and maximize profit and thereby endangering the life of the populace. What come to mind in the use of agricultural materials for metal removal is the availability and low cost sorbents for adsorption. In this study, the adsorbents used are usually disposed off indiscriminately into the environment and constitute environmental hazard to the public [12], particularly in the southern part of the country where they are widely available as reported by [17]. These sorbents can gainfully be employed to treat effluents from industries before being discharge into the environment. Several researchers, reported that the use of agricultural biomass of both plant and animal origin for the sorption of heavy metals from solutions [2] that the use of chemically treated periwinkle shells to remove lead and mercury from aqueous medium. Periwinkle shells are known to contain polar functional groups such as primary amines groups, hydroxyl groups, carboxylic acid groups and amide and phenolic groups.

\section{EXPERIMENTAL METHOD}

Heavy metal analysis was conducted using Varian AA240 Atomic Absorption Spectrophotometer according to the method of (American Public Health Association) (APHA, 1995). 
$2.0 \mathrm{~g}$ each of the finely grounded samples were thoroughly mixed by shaking, and $100 \mathrm{ml}$ of it was transferred into a glass beaker of $250 \mathrm{ml}$ volume, to which $5 \mathrm{ml}$ of concentrated nitric acid was added and heated to boil until the volume was reduced to about $15-20 \mathrm{ml}$, by adding concentrated nitric acid increments of $5 \mathrm{ml}$ till all the residue is completely dissolved. The mixture was cooled, transferred and made up to $100 \mathrm{ml}$ using metal free distilled water. The sample was aspirated into the oxidizing air- acetylene flame. When the aqueous sample was aspirated, the sensitivity for $1 \%$ absorption was observed. The quantity of each trace metal in each sample was calculated by proportion methods using the standard curve method.

\section{Sample Collection}

With clean dry plastic container sediments from Eagle Island River was collected at 25 sampling stations where periwinkles live. On collecting the sediment, the periwinkles found in each station was also picked and kept in their respective sediment containers. And this followed for all the sampling stations. The sample containers were covered to prevent the periwinkles from one station container to move to another station container.

\section{Sample preparation}

The shell of the fresh water periwinkle (Tympanotonosfuscatus) sample for each station were cracked and separated to obtain their tissue (edible parts). The tisstle separated was rinsed with severalchanges of distilled water and allowed to air dry. After which, sample for each station were blended or homogenized to powder form ion1 to station 25 and from which 2 grams of each was weighed using an electronic weighing balance. The weighed tissue sample for each station was transferred to a beaker labeled station 1 to station 25 . Into each of the beaker, was added $6 \mathrm{ml}$ of trioxonitrate (v) acid (HNO3) and $2 \mathrm{ml}$ of perchloric acid and stirred,30 $\mathrm{ml}$ of distilled water was also added. Each beaker was placed on the hot plate and heated for digestion to take place. After heating, the samples were allowed to cool. Then by means of funnel and filter paper, each of the samples labeled station 1 to station 25 were filtered. The filtrate was collected and the volume was made up to $50 \mathrm{ml}$ using the deionized water. Then the prepared samples were ready for Atomic Absorption Spectrophotometric analysis. The samples were analyzed for lead $(\mathrm{Pb})$ using lead hollow cathode lamp. The sample was aspirated into the burning flame.

\section{Sedimentation}

The sediments from each station were airdried, after which the samples were then powdered. The sediment particles were allowed to pass through $160 \mu \mathrm{g}$ sieve, from the sieved particles of the sediment, 1gram of the sediment was weighed using an electronic weighing balance. The weighed sediment was transferred to a beaker, followed by the addition of $3 \mathrm{ml}$ of nitric acid (HNO3) and $1 \mathrm{ml}$ of hydrochloric acid $(\mathrm{HCl})$ with $25 \mathrm{ml}$ of distilled water. After which the sample was heated for one hour. After heating, the mixture was allowed to cool, and then followed by filtration of the mixture using a Watman No.1 filter paper. Each of the heated mixtures representing sample station 1 to sample station 25 were allowed to cool, then filtered into a measuring cylinder and the volume was made up to $50 \mathrm{ml}$ using deionized water.

\section{RESULT}

Table-2: Compositions of Lead, Iron, Zinc and Mercury in periwinkle tissue in salt and fresh water Source of Periwinkle

\begin{tabular}{|l|l|l|}
\hline Heavy metals (mg/kg) & SWP & FWP \\
\hline Lead, $\mathrm{Pb}$ & 0.89 & 0.75 \\
\hline Iron, $\mathrm{Fe}$ & 3.35 & 3.08 \\
\hline Mercury, $\mathrm{Hg}$ & 0.54 & 0.46 \\
\hline Zinc. $\mathrm{Zn}$ & 0.92 & 0.57 \\
\hline
\end{tabular}

Key: SWP: Salt Water Periwinkle, FWP: Fresh Water Periwinkle

Table-2: Percentage Composition of Lead, Iron, Cadmium and Mercury in Periwinkle Tissue obtained from Salt and Fresh water

\begin{tabular}{|l|l|l|l|l|}
\hline \multicolumn{7}{|l|}{ Percentage Composition of heavy metals in Periwinkle } \\
\hline Heavymetals (mg/kg) & SWP & Percentage (\%) & FWP & Percentage (\%) \\
\hline Lead, $\mathrm{Pb}$ & 0.89 & 18.62 & 0.75 & 17.48 \\
\hline Iron, $\mathrm{Fe}$ & 3.35 & 70.08 & 3.08 & 71.79 \\
\hline Mercury, $\mathrm{Hg}$ & 0.54 & 11.29 & 0.46 & 10.72 \\
\hline Zinc. $\mathrm{Zn}$ & 2.95 & 53.34 & 2.40 & 48.28 \\
\hline
\end{tabular}

Key: SWP: Salt Water Periwinkle, FWP: Fresh Water Periwinkle

\section{DISCUSSION}

Table-1 shows the composition heavy metals analyzed shows the composition of the heavy metals analyzed which are lead, iron, zinc and mercury in peri winklet issue obtained from salt and fresh water bodies. These results indicate the various concentration of lead, iron, zinc and mercury present in salt water periwinkle (swp) and freshwater periwinkle (fwp). The presesnce of these heavy metals are attributed to the mineral nutrients and organic matters of both the fresh and salt water bodies. However, heavy metals like mercury and lead are toxic in nature when present in a system in high concentrations especially when it is beyond the 
permissible limits, this can lead to some serious hazards or disorders according to [9]. High concentrations of these metals in the periwinkle species can lead to some health challenges, particularly lead is known to present environmental problems generally because of its wide applications in industries. Recent toxicological studies in lead $(\mathrm{Pb})$ have shown that the metal is not only a neurotoxin but has been linked up with several symptoms such as fatique, loss of appetite, chronic anaemia, renal dysfunction, low sperm count and death according to [4]. The concentration in salt water periwinkles is higher considering the fresh water concentration [10]. Table-2 shows the actual percentages of the concenntrations of heavy metals analyzed comparatively between the salt water periwinkles and freshwater periwinkles. The results have clearly shown the comparative analysis as discussed in Table-1. However, the concentrations of lead and mercury are above world health standards in both salt water periwinkles and freshwater periwinkles, therefore excessive consumption of these sea foods may have some adverse effects, similarly reported by [1].

\section{CONCLUSION}

From the analysis carried out, lead and mercury concentrations in salt water periwinkles and salt water periwinkles are higher than the acceptable or permissible limits calls action. That the accumulation of Lead in periwinkle from this water is higher than acceptable tolerable limit calls for immediate concern. This is in view of the fact that by extrapolation, it may be possible that other sea foods from those rivers could be equally polluted and the ignorant populace keeps consuming these sea foods. Lead is named among the toxic metals that elicit adverse effects in humans such as behavioral and endocrine disturbances and as such high levels can be dangerous to human health and as such should be avoided. Other metals in this group include Iron and Mercury. The possibility is that there could equally be bioaccumulation of these heavy metals if consumed excessively and the attendant health implications at the long run. This paper therefore calls for adequate legislation on environmental protection of all water bodies, with the aim to protect the populace from untoward adverse effects that may arise from heavy metal poisoning'.

\section{REFERENCES}

1. American Public Health Association. (1995). Standard methods for the examination of dairy product, $15^{\text {th }}$ American public Health Association. New-York.

2. Flora, S. J. S., Mittal, M., \& Mehta, A. (2008). Heavy metal induced oxidative stress \& its possible reversal by chelation therapy. Indian Journal of Medical Research, 128(4), 501.

3. Markowitz, G., \& Rosner, D. (2000). " Cater to the children": the role of the lead industry in a public health tragedy, 1900-1955. American Journal of Public Health, 90(1), 36.
4. Udosen, E. D. (2000). Environmental Chemistry. Unpublished Book.

5. Udosen, E. D., Akpan, E. O., \& Sam, S. M. (2016). Levels of some heavy Metals in Cocoyam (Colocasia esculentum) grown on Soil receiving Effluent from a Paint Industry. Journal of Applied Sciences and Environmental Management, 20(1), 215-218.

6. Moslen, M., \& Miebaka, C. A. (2016). Temporal variation of heavy metal concentrations in Periophthalmus sp. Obtained from Azuabie Creek in the upper Bonny Estuary, Nigeria. Current Studies in Comparative Education, Science and technology, 3, 136-147.

7. Moslen, M., \& Miebaka, C. A. (2017). Concentration of heavy metals and health risk assessment of consumption of fish (Sarotherodon melanotheron) from an Estuarine Creek in the Niger Delta, Nigeria. IOSR J Env Sci, Toxicol Food Technol, 11, 68-73.

8. Moslen, M. (2017). Risk Assessment and Bioconcentration of Heavy Metals in Mugil Cephalus (Mullet) obtained from Azuabie Creek in Port Harcourt, Nigeria. J of Res in Environ and Earth Sci, 3, 1-7.

9. Ikejimba, C. C., \& Sakpa, S. (2014). Comparative study of some heavy metals' concentrations in water and Tympanotonus fuscatus var radula samples of Egbokodo River, Warri, Nigeria. International journal of Modern Biological Research, 2, 7-15.

10. Daka, E. R., Ifidi, I., \& Braide, S. A. (2006). Effect of size and salinity on the accumulation of heavy metals in the intertidal gastropod Tympanotonus fuscatus Linnaeus. African Journal of Environmental Pollution and Health, 5, 1-7.

11. Ekpo, F. E., \& Ukpong, E. J. (2014). Assessment of Heavy Metals Concentrations in water, Sediments and some common sea foods Callinectes amnicola and Tympanotonus fuscatus (crabs and periwinkles) from Uta Ewa Creek of Ikot Abasi, Akwa Ibom State, Nigeria. Global Journal of Applied Environmental Sciences, 4(1), 99-106.

12. FAO. (2003). Heavy Metals Regulations: Part 1. Legal Notice no. 66.

13. Daka, E. R., Ifidi, I., \& Braide, S. A. (2006). Effect of size and salinity on the accumulation of heavy metals in the intertidal gastropod Tympanotonus fuscatus Linnaeus. African Journal of Environmental Pollution and Health, 5:1-7.

14. Chindah, A. C., Braide, S. A., \& Chikwendu, S. O. N. (2009). Heavy metal concnetrations in sediment and periwinkle-Tympanotonus fuscastus in the different ecological zones of Bonny River system, Niger Delta, Nigeria. The Open Environmental Pollution \& Toxicology Journal, 1(1):93-106.

15. Ikejimba, C. C., \& Sakpa, S. (2014). Comparative study of some heavy metals' concentrations in 
water and Tympanotonus fuscatus var radula samples of Egbokodo River, Warri, Nigeria. International journal of Modern Biological Research, 2, 7-15.

16. Moslen, M., \& Miebaka, C. A. (2017). Concentration of heavy metals and health risk assessment of consumption of fish (Sarotherodon melanotheron) from an Estuarine Creek in the Niger Delta, Nigeria. IOSR J Env Sci, Toxicol Food Technol, 11, 68-73.

17. Moslen, M., \& Miebaka, C. A. (2016). Temporal variation of heavy metal concentrations in Periophthalmus sp. Obtained from Azuabie Creek in the upper Bonny Estuary, Nigeria. Current Studies in Comparative Education, Science and technology, 3, 136-147.

18. Ekweozor, I. K. E. (2014). Appraisal of industrialization and environmental pollution: A marine biology perspective. 29th Inaugural lecture of the Rivers State University of Science \& Technology, Port Harcourt, Nigeria. 185.

19. Dambo, W. B., \& Ekweozor, I. K. E. (2000). The determination of lead in mangrove oyster, Crassostrea gasar from the lower bonny estuary, Nigeria. J. App. Sc. \& Environ. Mgt, 4, 101-108.

20. Daka, E. R., Ifidi, I., \& Braide, S. A. (2006). Accumulation of heavy metals from single and mixed metal solutions by the gastropod mollusc Tympanotonus fuscatus linnaeus from a Niger Delta estuary: Implications for biomonitoring. African Journal of Biotechnology, 5(20):1954-1962.

21. Davies, O. A., Allison, M. E., \& Uyi, H. S. (2006). Bioaccumulation of heavy metals in water, sediment and periwinkle (Tympanotonus fuscatus var radula) from the Elechi Creek, Niger Delta. African Journal Biotechnology, 5(10):968-973. 